IZA DP No. 3526

Fertility in Sub-Saharan African Countries with Consideration to Health and Poverty

Yongil J eon

Sang-Young Rhyu

Michael P. Shields

J une 2008 


\title{
Fertility in Sub-Saharan African Countries with Consideration to Health and Poverty
}

\author{
Yongil Jeon \\ Central Michigan University \\ Sang-Young Rhyu \\ Yonsei University \\ Michael P. Shields \\ Central Michigan University \\ and IZA
}

Discussion Paper No. 3526

June 2008

IZA

P.O. Box 7240

53072 Bonn

Germany

Phone: +49-228-3894-0

Fax: +49-228-3894-180

E-mail: iza@iza.org

Any opinions expressed here are those of the author(s) and not those of IZA. Research published in this series may include views on policy, but the institute itself takes no institutional policy positions.

The Institute for the Study of Labor (IZA) in Bonn is a local and virtual international research center and a place of communication between science, politics and business. IZA is an independent nonprofit organization supported by Deutsche Post World Net. The center is associated with the University of Bonn and offers a stimulating research environment through its international network, workshops and conferences, data service, project support, research visits and doctoral program. IZA engages in (i) original and internationally competitive research in all fields of labor economics, (ii) development of policy concepts, and (iii) dissemination of research results and concepts to the interested public.

IZA Discussion Papers often represent preliminary work and are circulated to encourage discussion. Citation of such a paper should account for its provisional character. A revised version may be available directly from the author. 
IZA Discussion Paper No. 3526

June 2008

\section{ABSTRACT}

\section{Fertility in Sub-Saharan African Countries with Consideration to Health and Poverty ${ }^{*}$}

Fertility has begun to fall in Sub-Saharan Africa but it remains high on average and particularly for a few countries. This paper examines African fertility using a panel data set of 47 Sub-Saharan countries between 1962 and 2003. Fixed and random country effect estimates are made in models where the explanatory variables are suggested by the theory of the demographic transition as modified by Caldwell. Special attention is paid to the economic status of women, urbanization, the poverty level, and the health of the population including total health expenditures and the prevalence of HIVIAIDS. The results support Caldwell's hypothesis and are generally supportive of hypothesis that a fertility transition is occurring. HIVIAIDS is found to have a negative impact on fertility.

JEL Classification: J13, O10, O55

Keywords: fertility, infant mortality, Africa, poverty, health

Corresponding author:

Michael P. Shields

Department of Economics

Central Michigan University

Mt. Pleasant, MI 48859

USA

E-mail: Michael.P.Shields@cmich.edu

\footnotetext{
* The authors are grateful to Zhigang Deng and Adam T. Battle at Central Michigan University for their excellent assistance. The authors remain responsible for any remaining errors.
} 


\section{Introduction}

While birth rates have fallen dramatically throughout much of Asia and Latin America, they have remained high in Sub-Saharan Africa. Sub-Saharan Africa is a region for which the demographic transition has not been well underway. Fertility, however, is not uniformly high and has fallen on average from a total fertility rate (TFR) of 6.54 in 1962 to 5.02 in 2002. The precursors of the demographic transition are increased prosperity, an improved status of women, a higher level and growth rate of urbanization, improved health services and lower infant mortality. Since many African countries still remain in a relatively high level of fertility, they offer a good opportunity to early transitional fertility and, to a lesser extent, pre-transitional fertility.

We will examine the impact of poverty, health, and female labor force participation on fertility. We will also examine the relationship between infant mortality and fertility in Africa. In transition theory, a declining death rate is thought to eventually lead to a lower fertility rate. In the Sub-Saharan African countries, there has been a dramatic increase in death rates due to HIV/AIDS (Human Immunodeficiency Virus), which is not true in other countries. Thus, we will examine whether this increase has lead to higher fertility. Countervailing factors such as campaigns for lower birth rates by the government and by nonprofit organizations and international organizations such as the World Bank may have played a role in lowering fertility. Also, the use of systematic family planning programs was executed in this area.

In this paper, we explore the impact of socioeconomic and policy-oriented variables on fertility, with a panel data set of 47 Sub-Saharan countries between the period of 1962 and 2003. ${ }^{1}$ Sub-Saharan Africa is an important region to study in part because it has lagged behind other region both in terms of economic development and in terms of completing the demographic transition. There has been an abundance of empirics on African fertility using cross-sectional regional data or using cross-sectional survey data. ${ }^{2}$ There have, however, been almost no empirical studies we know of using country data through time. One reason for the absence these time series models of African fertility is the lack of regular series of data for key variables. This study will

\footnotetext{
${ }^{1}$ The data are from the World Development Indicators, 2005.

${ }^{2}$ See Schultz (1997).
} 
overcome these data limitations by using both pooled and panel data methods to test key hypotheses about fertility in Sub-Saharan Africa.

Special attention is paid to infant mortality, the economic status of women, urbanization (both level and growth rate), poverty, and the health status of the population including total health expenditure and the prevalence of HIV. Section 2 gives a brief discussion of the theory of the demographic transition and how it has been modified by Caldwell (1982) to fit the experiences of African countries. Section 3 provides an overview of the empirical literature on the transition in the Sub-Saharan African economies over time and discussions on specific countries. Section 4 describes the data set and our models for fertility in African economies. Then, we discuss the empirical findings and the missing data problem which is regarded as a key issue to solve. Section 5 summarizes our conclusions and the policy implications of our findings.

\section{Demographic Transition Theory for Sub-Saharan Africa}

Much of the research on fertility in less developed countries is based on the theory of the demographic transition. Transition theory is based on functionalism (see Parsons, 1937), where individual behavior is viewed as satisfying group needs through group enforcement of social norms and mores. In this theory (see Notestein, 1949) prior to modernization or economic development, mortality was high and in order for a society to be viable, social norms and mores evolved to encourage high fertility. With the onset of economic development, mortality fell but fertility remained high because social norms and mores had not adjusted to the new reality. Eventually, however, social norms and mores may adjust to society’s new needs. If so, fertility falls to replacement levels.

Numerous social institutions and customs are thought to have arisen to support high fertility. The theory postulates that with development, these institutions and customs will change causing fertility to fall. Particular attention is placed on children as a production input for family enterprise and as a source of retirement support. Urbanization, and rising economic opportunities for women have also been emphasized.

Early evidence for transition theory was based on the experience of European countries in the early stages of industrialization, but it has had to be revised given the 
experience of developing countries. For example, Dyson and Murphy (1985) point out that fertility rates have often risen with modernization instead of remaining stagnant and high as transition theory predicts. Caldwell (1982) develops a revised transition theory for Africa based on this observation that fertility initially rises with modernization. His theory is explicitly based on the African experience.

Caldwell bases his revision on the role of the extended family in Africa in providing various types of security and his introduction of the concept of wealth transfers. Wealth transfers occur among extended family members in times of economic need. Old age pensions, stressed in standard transition theory may only be a small part of these transfers. When one family member faces economic hardship due to crop failure, job loss or other periodic hardships, family members offer financial assistance. Hence, these wealth transfers substitute for the social insurance and social security programs present in developed countries.

Caldwell explains the initial rise in fertility observed by Dyson and Murphy in terms of these transfers. If all family members grow the same crop in the same region, they may not be able to help each other in times of economic hardship. However, if they have different occupations, grow different crops, live in different regions, and so forth, the likelihood that they will all face economic hardship at the same time is reduced. They are, in a sense, reducing and sharing risk by increasing the number of different income sources for the family as a whole. Caldwell contends that modernization allowed families to diversify this occupational mix and, hence, to reduce risk.

When modernization began in Africa, the expansion of the modern sector allowed extended families to reduce risk because young adults could be employed in the modern sector in a wide variety of occupations. Incomes in this modern sector are not likely to be highly correlated with incomes in traditional agriculture and the expansion of the modern sector presents opportunities for large families to reduce risk as long as there are wealth transfers within the extended family. Hence, the expansion of the modern sector creates an incentive for having a larger family because larger families can reduce risk by taking modern sector employment and by choosing a more diverse number of careers. Therefore, it might be expected that fertility would initially rise with modernization. 
This increase in fertility will be temporary because the strength of the bonds tying members of an extended family together will begin to weaken. These bonds will weaken with time and distance. Many of the modern sector jobs will be in urban areas, which may be some distance for the homestead and may have a different cultural environment. The bonds may be strong after moving, but eventually they will start to weaken. As a consequence, fertility in Caldwell's theory will begin to fall.

Due to data limitations, a direct empirical test of Caldwell's wealth-transfer hypothesis may not be possible. Nonetheless, we can test some of its implications. The flow of immigrants into urban areas may represent the diversification of occupations. In Caldwell's hypothesis this diversification is an incentive for having more children. Hence the rate of growth of the urban population should be positively related to fertility if Caldwell's hypothesis holds. However, recent migrants to the city may only be a small percentage of the urban population. Hence, the stock of urban dwellers will largely consist of past migrants and second generation urbanites both of whom have weakened extended family ties. Hence, the normal influences of urban life such as an increased cost of child rearing are felt by the parents. These effects will be stronger than the diversification effect. Thus the percentage of the population that is urban may be negatively related to fertility while the growth rate of the urban population may be positively related to fertility. Hence, these two variables will be included in the empirical model along with other selected socioeconomic variables based in part on the experience of sub-Saharan Africa to obtain an empirical description of fertility in sub-Saharan Africa. These signs of these two urban variables will provide an indirect test of Caldwell's hypothesis. We will now briefly discuss this experience.

\section{Fertility Patterns in Sub-Saharan Africa}

Sub-Saharan Africa is an important region to study partly because its fertility has been and remains extremely high. If the region is to prosper, it would appear that fertility must eventually fall. Hence, the question of whether economic development will lead to a fertility transition is important. Another reason for studying Sub-Saharan Africa concerns the high rates of HIV/AIDS for many countries in the region. HIV/AIDS threatens to dramatically alter the course of population growth in the region. It is an open 
question, as we shall see, whether this epidemic will hasten or retard the fertility transition.

In 1962 virtually all countries in Sub-Saharan Africa had a reported total fertility rate above 6.0 with an average of 6.54. The most notable exception was Gabon at 4.06. Eleven countries had total fertility rates above or equal to 7.0 with Kenya reporting a total fertility rate of 8.12 , which is one of the highest total fertility rates ever reported for a country. Fertility has fallen but remains high with an average total fertility rate of 5.02. This decline opens up the possibility that fertility in Sub-Saharan Africa is responding to economic change.

The decline in African fertility, however, is uneven. Some countries like Botswana have seen considerable decline. From 1962 to 2003 the total fertility rate fell in Botswana from 6.90 to 3.74, in Mauritius from 5.72 to 1.97, and in South Africa from 6.51 to 2.80. These countries have witnessed considerable socioeconomic change. Hence, a high fertility rate is associated with stagnant economies. Fertility in Angola, Chad, the Democratic Republic of Congo, the Republic of Congo, Guinea-Bissau, Niger and Somalia, has remained at its previously high levels or, in a few cases, have actually risen.

As noted earlier, studies of fertility in Sub-Saharan Africa have almost exclusively been cross-sectional studies of a single country studies using either regional data or microeconomic survey data. An exception is Kalemli-Ozcan (2006) which looks at the impact of HIV/AIDS on fertility within the region for pooled data and finds that the incidence of AIDS in 1985 is positively related to subsequent fertility. Before seeing if these results hold in our model, we will briefly discuss the results from selected studies using micro survey data for Kenya, Nigeria and South Africa. While these studies do capture microeconomic aspects of transition theory, they can not directly test transition theory, which is explicitly a theory of macroeconomic behavior.

Dow et al (1994) and Robinson (1992) examine surveys for Kenya. Based on a comparison of a fertility survey conducted in 1977-78 with a survey conducted in 1989, Robinson concludes that contraceptive use rates have risen from $12.4 \%$ to $27 \%$ and that fertility has fallen as a consequence. He attributes this fertility decline to changing attitudes about family size and family planning. Dow et al examine the impact of 
intergenerational transfers of wealth on fertility and conclude that the declining strength of wealth transfer relations between 1981 and 1992 is at least partially responsible for a decline in fertility. Hence, both studies support Caldwell's revision of transition theory.

Smith (2004) examines a survey of Nigeria and investigates condom use and perceptions of the risks of HIV infection. He concludes that, while condom use is widespread (about $40 \%$ of those in his sample), its use is largely determined by social norms regarding contraception and fertility and that condom use is not primarily a response to fears of AIDS. Hence, AIDS may not reduce fertility through increased contraception.

Caldwell and Caldwell (1993) and Moulttie and Timaeus (2003) compare several fertility surveys and census data for South Africa. Caldwell and Caldwell argue that the demographic transition is well under way in South Africa but they do not conjecture about which variables are responsible for the fertility decline. Moulttie and Timaeus find that the fertility rate has fallen to 3.5 births per woman and they attribute much of this decline to urbanization and an increased availability of contraception. They also argue that rising HIV/AIDS will further reduce fertility for three reasons. First, HIV/AIDS will increase maternal deaths leading to lower births per woman due to the truncated cohorts of women. Second, HIV/AIDS will lead to secondary sterility of infected women. Third, infected women may choose to avoid childbearing. ${ }^{3}$

In this study, five types of explanatory variables are considered. First, we look at two variables directly related to Caldwell's wealth transfer model. These variables are the level (percent urban) and the growth rate of the urban population. As explained previously, the level is expected to be negatively related to fertility and the growth rate is expected to be positively related to fertility. Second, we look at the relationship between mortality, particularly infant mortality, and fertility. A negative relationship is expected. Third, we look at women's labor force participation. A negative relationship with fertility is expected. Fourth, we look at income and fertility, again expecting a negative relationship. Finally, we look at health related variables and fertility.

Before considering the empirical analysis, we will briefly discuss the health related variables including the infant mortality rate, and the AIDS infection rate. Several

\footnotetext{
${ }^{3}$ For further discussion of HIV/AIDS and fertility in Africa see Crook (1997).
} 
factors are thought to cause the infant mortality rate to fall in demographic transition theory. They include industrialization, urbanization, improvements in living standards, literacy, and improvements in medical practices. The decline in infant mortality is thought to be followed by a fertility decline. There is no consensus on the causality between infant mortality and fertility, as shown by Chowdhury $(1988)^{4}$, who infers that most of the existing literature uses cross-sectional data with visual data inspection. Instead, he performs Granger-causality tests with annual time series for each of the thirtyfive developing countries, reporting the lack of consistent results across different countries with only weak support for transition theory, in general. ${ }^{5}$

We will examine the impact of infant mortality on fertility for a panel of subSaharan African countries along with other health related variables. A health related variable that is increasing in importance to Africa is AIDS. African countries have seen a dramatic increase in deaths due to AIDS. The impact of this threat on fertility is unclear. In part HIV/AIDS increases mortality and could eventually increase infant mortality due to increased difficulties in providing health care and sustenance to infants resulting from these deaths. Therefore, we can model fertility rates with three related variables. These variables are a health variable, HIV/AIDS and the infant mortality rate (which is high in some African countries). The question is how each of these variables will impact birth rates. We will examine these themes because of their potential importance for fertility and policy.

\section{Empirical Analysis with missing value problem}

The data are provided by the World Bank in World Development Indicators 2005. Tables 1-2 give some aggregate statistics for variables used in the models. Demographic

\footnotetext{
${ }^{4}$ Both demographic transition theory and choice theory indicate that the causality of infant mortality to fertility is due to reducing the necessity of preservation and raising the cost of surviving children. The Ricardian theory suggests the opposite effect, indicating that causality is from high birth rates to infant mortality. And lastly, the modern economic theory on population shows interdependence between these variables.

${ }^{5}$ The data set that Chowdhury (1988) uses includes 10 Sub-Saharan African countries - Ethiopia Ghana, Kenya, Somalia, Sudan, Tanzania, Zaire, Cameroon, Ivory Coast, and Nigeria. 2 countries (Ethiopia and Sudan) show the Granger-causality of fertility on infant mortality, one country (Tanzania) indicates the other direction, five countries indicate interdependence (Ghana, Zaire, Cameroon, Ivory Coast, Nigeria the last three are middle-income countries) supporting the modern economic theory on population, and two countries (Kenya and Somalia) show no causality.
} 
variables are shown in Table 1 while policy variables are shown in Table 2. Tables 3 and 4 give aggregate statistics for these same variables by year. In the Sub-Saharan region data for 48 countries are available. The data for Mayotte are not available for these variables. Thus, we provided the summary statistics for 47 countries in Tables 1-4. However, when the regression is run, there are 41 countries in the basic model, and 40 countries remain in the extended model. The data are pooled by accumulating the 42 year dataset between 1962 and 2003. Although more annual data are used (one year to 42 years), the data observations used in the regression only increases from 41 to 91 in the basic model settings. However, the results are quite similar. This increases slightly due to interpolating missing values of the fertility rate. Thus, we interpolate the total fertility rate by fitting linear polynomials. That is, when two observations $y_{t}$ and $y_{t+h}$ are known but values between two are missing, we fill in those missing values by $y_{t+k}=y_{t}+k \times\left(\frac{y_{t+h}-y_{t}}{h}\right)$ with $k=1,2, \ldots, h-1$. Interpolation for missing values are made mostly in the 6 years: 1980,1990, 1995, 2000, 2002, and 2003, when other independent variables are available. After the interpolation, the numbers of observations used in the regressions almost doubles, but the results remain almost identical. When the basic model is run with the interpolated fertility rate, the number of observations becomes 204 and its results are similar to that of original fertility data. Furthermore, the extended model includes 198 observations, where the percentage of the urban population is additionally significant.

Table 5 shows the results for the first set of regressions. Two models are estimated. The first model is called the basic model, where fertility is estimated as a function of the infant mortality rate and per capita GDP. The second model, the extended model, includes the variables in the basic model but adds the percent of the population that is urban, the growth rate of the urban population, and the female labor force participation rate. These models are estimated for a selected year and for the pooled data set. First, a cross-sectional estimate is shown for the year 1990. 1990 was chosen because for total fertility, infant mortality and GDP per capita are mostly available in 1990 (confirmed from Tables 3-4). The results of the basic model hold when it is extended to include the additional variables so we will only discuss the extended models. 
Three independent variables are significant with both the normal and robust standard errors. That is, as the infant mortality rate falls, the total fertility rate falls. Similarly, when GDP per capita increases, the total fertility rate decreases. Both these results are predicted by most versions of transition theory. Finally, the growth rate of the urban population increases fertility as Caldwell contends. The percentage of the urban population and female labor participation are not significant. The insignificance of female labor participation seems unique in Sub-Saharan African countries, since other regions including European countries (Jeon and Shields (2005)) and Asian countries (Jeon, Shields and Rhyu (2007)) indicate that it has a negative significance. Strong support by extended families may make it easier for an African woman to raise a large family while she is employed in the market. The results are similar for the pooled resulted and the results with interpolated data. Furthermore, the regressions provide $\mathrm{R}^{2}$ and adjusted $\mathrm{R}^{2}$ ranges of 0.617 and 0.795 , which indicates a reasonably good fit.

Table 6 provides a robust check for the dependent variable. Table 5 is based on the total fertility rate, and Table 6 is calculated from the crude birth rate. Both tables provide similar results with the same number of observations. Thus, it is claimed that our results are robust to the different definitions of the birth rates. The only differences are on the insignificant urban population variable, and on the female participation variable that is significant under normal standard errors, but insignificant under heteroscedastic robust standard errors.

Due to the data availability of the infant mortality variable, the number of observations in running regressions was restricted. That is, the infant mortality variable is available exclusively in 1970, 1980, 1990, 1995, 2000, and 2003. ${ }^{6}$ Two panel model specifications are estimated (shown in Table 7), the fixed effects and the random effects models, both of which are selected by the Hausman test which hypothesizes that the unobserved individual-level effects are modeled by random effects estimation. That is, the fixed effects model is selected for the basic model setting, but the random effects model is chosen for the extended model specification. In both model settings with country fixed effects, GDP per capita becomes insignificant since the impact of GDP on

\footnotetext{
${ }^{6}$ However, this limited data structure can be fully analyzed with the panel data structure. Since the data on 1970 are limited, they are dropped. It is worth noting that year 2003 is the last available year in our data set.
} 
fertility is correlated with the country-specific fixed effect. However, the infant mortality variable remains positively significant in both specifications. In the extended model under the random effects estimation, female labor participation is not significant, which confirms the results in Table 5 and Table 6. But, both urban population percentage and growth rate are jointly statistically significant. In other words, the level of urban population is negatively significant while its growth rate is positively significant on the dependent variable. In summary, the panel analysis in Table 7 confirms our findings in pooled estimations in Tables 5 and 6, except for two cases, the correlation of GDP and country fixed effects, and joint significance of both the level and growth rate of urban population.

Table 8 explores several policy questions, starting from the social structure framework containing the total fertility rate modeling. Pooled estimate are shown. The benchmark model is adopted from the basic fertility model with the interpolated fertility rate between 1962 and 2003 in Table 5. This benchmark model includes 204 observations with a model fit of 0.621 in $\mathrm{R}^{2}$. The dependent variable, total fertility rate per women, is defined as the number of children that would be born to a woman if she were to live to the end of her childbearing years and bear children in accordance with prevailing agespecific fertility rates. Among the independent variables, the "infant mortality rate" is the number of infants dying before reaching one year of age, per 1,000 live births in a given year. The GDP per capita is in constant (year 2000) U.S. dollars of gross domestic product divided by midyear population. We experiment with several different policy models by adding a policy variable group one at a time, since the data limitation does not allow us to build the complete model.

First, we added two additional variables, the female adult mortality rate and the male adult mortality rate. These variables were added as a robustness check to the standard assumption that it is only infant mortality that affects fertility. The adult mortality rate is the probability of dying between the ages of 15 and 60 subject to current age-specific mortality rates between ages 15 and 60 . Table 8 indicates that none of them are statistically significant.

Second, total prevalence of HIV is added, where the prevalence of HIV refers to the percentage of people aged 15 and 49 who are infected with HIV. This variable is 
available only in years 2001 and 2003, thus it is assumed that the data for 2000 is the same with that of 2001. This HIV variable is statistically significant; however, a higher percentage of HIV leads to a lower total fertility rate. This result supports the conclusions of Smith (2004) and Moulttie and Timaeus (2002) and contradicts the finding of KalemliOzcan (2006). Hence, parents react differently to HIV than to other sources of mortality. While mortality in general is positively associated with fertility, HIV and its resulting mortality is not offset by higher fertility. Therefore, this could mean that HIV could result in depopulation because of the absence of any countervailing rise in births. HIV might result in lower fertility in part because it decreases the likelihood that parents will live long enough to enjoy the benefits of having children.

Third, total health expenditure is added as a percentage of GDP. This variable covers the provision of health services (preventive and curative) such as, family planning activities, nutrition activities, and emergency aid designated for health but not regarding the provision for water and sanitation. No adjustment for missing values is attempted and this variable is not statistically significant at the $5 \%$ significance level. As another modeling strategy, two health variables are added together in the regression. Still the same results are applied, the HIV variable is statistically significant but the health expenditure variable is insignificant.

Fourth, the poverty headcount ratio at PPP \$1 per day, as the percentage of population, is added in our benchmark model (Model 5). Population below PPP \$1 a day is the percentage of the population living on less than $\$ 1.08$ a day at 1993 international prices. As a robust check, the poverty headcount ratio at PPP \$2 per day is added (Model 6) which represents the percentage of the population living on less than $\$ 2.15$ a day. Due to the data limitation, we make an assumption that if the data in a specific year is missing, it can be filled in with an adjacent year within 2 years. For example, if the data are missing for year 1990, then we check the data for year 1991. If the data for year 1991 are still missing, we consider the data availability for year 1989. If these data are also missing, we try again with year 1992 and year 1988 and so forth. We apply this missing value adjustment only for the years, 1980, 1990, 1995, and 2000. The results indicate that both poverty variables are statistically significant. Hence, while higher income may 
reduce fertility the distribution of that income is important. Countries with lower rates of poverty have lower fertility for any give level of per capita income.

\section{Conclusion}

While fertility remains high in Sub-Saharan Africa, it has been falling for many countries. Some questions we have addressed regarding African fertility are as follows: Is there evidence to support Caldwell's African transition theory? How do income and the poverty rate affect African fertility? How do infant mortality and health affect African fertility? Does the economic status of women affect African fertility? And has the recent threat of HIV affected African fertility? Despite severe data limitations, there appears to be credible answers to these questions.

We find support for several propositions of transition theory as revised by Caldwell. First, the level of urbanization is negatively related to fertility as expected in transition theory. Second, expansion in the level of urbanization is positively related to fertility. This supports Caldwell's hypothesis that an increase in the size of the modern sector will increase fertility. Third, infant mortality rates are negatively related to fertility supporting what is perhaps the signature assumption of transition theory.

Another implication of transition theory concerns the impact of development on income. Higher income is thought to eventually lead to lower fertility. We discovered a more complicated relationship. While there is some evidence to support this negative income/fertility relationship, the distribution of income may also be important. Poverty is positively related to fertility, and thus a rise in per capita income will have its strongest negative impact on fertility if the improvement is widespread reducing the proportion of the population in poverty.

Finally, female participation in the labor market does not seem to be important in explaining fertility in Sub-Saharan Africa. This result is surprising given the presumed endogeneity of this variable. Typically women are assumed to leave the labor market in order to have children. The heavy reliance of African families on home production might 
explain the insignificance of female labor force participation in relation to African fertility. ${ }^{7}$

The most important health variable is the prevalence of HIV. Health expenditures are not significant while the prevalence of HIV is negative and statistically significant. This result indicates that policy to prevent AIDS may be working. Higher rates of infection may lead to greater condom use which reduces fertility.

\footnotetext{
${ }^{7}$ In addition, the impact of tribal conflicts on fertility within the country is viewed as a human security issue, which is in our research agenda.
} 


\section{REFERENCE}

Caldwell, John C. (1982) Theory of Fertility Decline, (New York: Academic Press).

Caldwell, John C. and Pat Caldwell (1993) "The South African Fertility Decline," Population and Development Review, 19 (June):225-62.

Caldwell, John C. (1994) "Fertility in Sub-Saharan Africa: Status and Prospects," Population and Development Review 20:179-87.

Caldwell, John C., I.O. Orubuloye, and Pat Caldwell (1992) "Fertility Decline in Africa: A New Type of Transition?” Population and Development Review 18: 211-42.

Chimere-Dan, Orieji (1997) "Recent Fertility Patterns and Population Policy in South Africa,” Development Southern Africa 14:1-20.

Chowdhury, Abdur R. (1988), “The Infant Mortality-Fertility Debate: Some International Evidence”, Southern Economic Journal, 54(3), 666-674.

Cohen, Barney (1998) “The Emerging Fertility Transition in Sub-Saharan Africa,” World Development 26:1431-1461.

Crook, Nigel (1997), Principles of Population and Development: with Illustrations from Asian and Africa, Oxford University Press.

Dow, Thomas E., Jr., Linda Archer, Shanyisa Khasiani and John Kekevole (1994) "Wealth Flow and Fertility Decline in Rural Kenya: 1981-92," Population and Development Review, 20 (June):343-64.

Dyson, Tim and Mike Murphy (1985) "The Onset of Fertility Transition," Population and Development Review, 11 (September):399-440.

Jeon, Yongil and Michael P. Shields (2005) "The Easterlin Hypothesis in the Recent Experience of Higher-Income OECD Countries: A Panel-Data Approach.” Journal of Population Economics, 18 (March 2005):1-13.

Jeon, Yongil, Sang-Yong Rhyu and Michael P. Shields 2007 "Asian Demographic Transition and Relative Cohort Size: An Instrumental-Variables Panel Approach,” working paper, Monash University.

Kalemli-Ozcan, Sebnem (2006) "AIDS, Reversal of the Demographic Transition and Economic Development: Evidence from Africa,” NBER Working Papers: 12181.

Moulttie, Tom A. and Ian M. Timaeus (2003) "The South African Fertility Decline: Evidence from Two Censuses and a Demographic Health Survey,” Population Studies, 57 (November):265-83. 
Notestein, Frank W. (1949) "Population -- the Long View," in Food for the World, ed. Theodore W. Schultz, (Chicago: University of Chicago Press, 1949), pp. 36-57.

Parsons, Talcott (1937) The Structure of Social Action, v. 1, New York: MacMillan.

Robinson, Warren C. (1992) “Kenya Enters the Fertility Transition,” Population Studies, 46(3):445-457.

Schultz, T. Paul (1997) “Demand for Children in Low Income Countries,” in Handbook of Population and Family Planning, ed. Mark R. Rosenzweig and Oded Stark, Amsterdam: Elsevier, Ch. 8.

Smith, Daniel J. (2004) “Premarital Sex, Procreation, and HIV Risk in Nigeria,” Studies in Family Planning, 35(4):223-235. 
Table 1: Summary Statistics for demographic variables across regions

\begin{tabular}{|c|c|c|c|c|c|c|c|c|c|c|}
\hline country & $\begin{array}{c}\text { number } \\
\text { of } \\
\text { countries }\end{array}$ & $\begin{array}{c}\text { total } \\
\text { fertility } \\
\text { (interpolated) }\end{array}$ & $\begin{array}{c}\text { crude } \\
\text { fertility } \\
\text { (interpolated) }\end{array}$ & $\begin{array}{c}\text { infant } \\
\text { mortality } \\
\text { rate }\end{array}$ & $\begin{array}{c}\text { GDP } \\
\text { per } \\
\text { capita }\end{array}$ & $\begin{array}{c}\text { urban } \\
\text { population } \\
\text { percentage }\end{array}$ & $\begin{array}{c}\text { urban } \\
\text { population } \\
\text { growth }\end{array}$ & $\begin{array}{c}\text { female } \\
\text { labor } \\
\text { participation }\end{array}$ & $\begin{array}{c}\text { mortality } \\
\text { rate } \\
\text { female }\end{array}$ & $\begin{array}{c}\text { mortality } \\
\text { rate } \\
\text { male }\end{array}$ \\
\hline Total & 47 & 6.08 & 43.65 & 104.79 & 2088 & 42.71 & 5.44 & 25.49 & 396.52 & 471.58 \\
\hline Central & 5 & 6.47 & 45.19 & 115.60 & 1110.35 & 46.78 & 4.94 & 22.87 & 444.05 & 531.07 \\
\hline East & 8 & 6.06 & 43.04 & 88.29 & 887.56 & 43.45 & 5.54 & 20.27 & 391.19 & 466.69 \\
\hline Southern & 13 & 5.69 & 41.70 & 91.42 & 3336.02 & 42.04 & 5.69 & 25.27 & 394.26 & 464.01 \\
\hline West & 21 & 6.25 & 44.72 & 116.79 & 1870.86 & 41.86 & 5.34 & 28.12 & 388.63 & 463.97 \\
\hline
\end{tabular}

Table 2: Summary Statistics for policy variables across regions

\begin{tabular}{|c|c|c|c|c|c|c|c|}
\hline & $\begin{array}{c}\text { number } \\
\text { of countries }\end{array}$ & $\begin{array}{c}\text { total } \\
\text { fertility }\end{array}$ & $\begin{array}{c}\text { crude } \\
\text { fertility }\end{array}$ & $\begin{array}{c}\text { prevalence of } \\
\text { HIV (15-49) }\end{array}$ & $\begin{array}{c}\text { health } \\
\text { expenditure }\end{array}$ & $\begin{array}{c}\text { poverty headcount } \\
\text { ratio at \$1 a day }\end{array}$ & $\begin{array}{c}\text { poverty headcount } \\
\text { ratio at \$2 a day }\end{array}$ \\
\hline Total & 47 & 5.95 & 43.09 & 8.93 & 5.04 & 42.35 & 71.69 \\
\hline Central & 5 & 6.39 & 44.72 & 6.80 & 3.65 & 53.39 & 84.92 \\
\hline East & 8 & 5.90 & 42.48 & 4.99 & 4.91 & 47.82 & 77.50 \\
\hline Southern & 13 & 5.51 & 41.00 & 19.78 & 5.61 & 36.62 & 63.51 \\
\hline West & 21 & 6.12 & 44.23 & 3.61 & 5.06 & 42.57 & 73.40 \\
\hline
\end{tabular}


Table 3: Summary Statistics for demographic variables over years 1962-2003

\begin{tabular}{|c|c|c|c|c|c|c|c|c|c|}
\hline year & $\begin{array}{c}\text { total } \\
\text { fertility } \\
\text { (interpolated) }\end{array}$ & $\begin{array}{c}\text { crude } \\
\text { fertility } \\
\text { (interpolated) }\end{array}$ & $\begin{array}{c}\text { infant } \\
\text { mortality } \\
\text { rate } \\
\end{array}$ & $\begin{array}{c}\text { GDP } \\
\text { per } \\
\text { capita }\end{array}$ & $\begin{array}{c}\text { urban } \\
\text { population } \\
\text { percentage }\end{array}$ & $\begin{array}{c}\text { urban } \\
\text { population } \\
\text { growth rate }\end{array}$ & $\begin{array}{c}\text { female } \\
\text { labor } \\
\text { participation }\end{array}$ & $\begin{array}{l}\text { mortality } \\
\text { rate } \\
\text { female }\end{array}$ & $\begin{array}{c}\text { mortality } \\
\text { rate } \\
\text { male } \\
\end{array}$ \\
\hline 1962 & 6.54 & 47.76 & & & 42.67 & 6.46 & 14.18 & & \\
\hline 1963 & 6.55 & 47.72 & & & 42.67 & 6.23 & 14.60 & & \\
\hline 1964 & 6.55 & 47.61 & & & 42.66 & 6.04 & 15.03 & & \\
\hline 1965 & 6.55 & 47.46 & & & 42.66 & 5.88 & 15.46 & & \\
\hline 1966 & 6.55 & 47.38 & & & 42.64 & 6.55 & 15.93 & & \\
\hline 1967 & 6.55 & 47.18 & & & 42.63 & 6.35 & 16.41 & & \\
\hline 1968 & 6.55 & 47.15 & & & 42.62 & 6.16 & 16.89 & & \\
\hline 1969 & 6.56 & 47.01 & & & 42.60 & 5.96 & 17.37 & & \\
\hline 1970 & 6.56 & 46.96 & 141.58 & & 42.59 & 5.75 & 17.85 & 412.95 & 503.43 \\
\hline 1971 & 6.56 & 46.89 & & & 42.60 & 6.45 & 18.41 & & \\
\hline 1972 & 6.56 & 46.82 & & & 42.60 & 6.24 & 18.96 & & \\
\hline 1973 & 6.56 & 46.68 & & & 42.61 & 6.08 & 19.52 & & \\
\hline 1974 & 6.57 & 46.26 & & & 42.62 & 5.96 & 20.07 & & \\
\hline 1975 & 6.57 & 46.11 & & 1912 & 42.63 & 5.86 & 20.63 & & \\
\hline 1976 & 6.53 & 46.02 & & 2000 & 42.62 & 6.19 & 21.22 & & \\
\hline 1977 & 6.54 & 45.85 & & 1935 & 42.61 & 6.14 & 21.81 & & \\
\hline 1978 & 6.52 & 45.75 & & 1886 & 42.61 & 6.06 & 22.41 & & \\
\hline 1979 & 6.50 & 45.49 & & 1887 & 42.61 & 5.94 & 23.00 & & \\
\hline 1980 & 6.48 & 45.35 & 117.58 & 2118 & 42.63 & 5.84 & 23.60 & 376.65 & 457.96 \\
\hline 1981 & 6.47 & 45.13 & & 2068 & 42.64 & 5.80 & 24.21 & & \\
\hline 1982 & 6.47 & 44.83 & & 2014 & 42.65 & 5.72 & 24.82 & & \\
\hline 1983 & 6.43 & 44.67 & & 1983 & 42.66 & 5.62 & 25.44 & & \\
\hline 1984 & 6.39 & 44.51 & & 1990 & 42.66 & 5.49 & 26.05 & & \\
\hline 1985 & 6.34 & 44.31 & & 1995 & 42.67 & 5.43 & 26.67 & & \\
\hline 1986 & 6.30 & 44.13 & & 2021 & 42.67 & 5.38 & 27.32 & & \\
\hline 1987 & 6.24 & 43.95 & & 1988 & 42.68 & 5.40 & 27.98 & & \\
\hline 1988 & 6.16 & 43.64 & & 2015 & 42.68 & 5.20 & 28.64 & & \\
\hline 1989 & 6.08 & 43.32 & & 2065 & 42.68 & 5.12 & 29.29 & & \\
\hline 1990 & 6.01 & 43.01 & 100.83 & 2020 & 42.68 & 5.07 & 29.95 & 352.89 & 427.17 \\
\hline 1991 & 5.93 & 42.67 & & 2012 & 42.70 & 5.01 & 30.58 & & \\
\hline 1992 & 5.86 & 42.35 & & 1957 & 42.72 & 4.91 & 31.21 & & \\
\hline 1993 & 5.77 & 41.84 & & 1919 & 42.74 & 4.65 & 31.84 & & \\
\hline 1994 & 5.67 & 41.34 & & 1968 & 42.76 & 3.93 & 32.47 & & \\
\hline 1995 & 5.57 & 40.90 & 97.47 & 1985 & 42.78 & 4.63 & 33.10 & & \\
\hline 1996 & 5.49 & 40.50 & & 2056 & 42.80 & 4.66 & 33.74 & & \\
\hline 1997 & 5.41 & 40.04 & & 2111 & 42.81 & 5.11 & 34.37 & 423.17 & 480.17 \\
\hline 1998 & 5.34 & 39.59 & & 2142 & 42.82 & 4.56 & 35.01 & & \\
\hline 1999 & 5.27 & 39.13 & & 2324 & 42.84 & 4.48 & 35.64 & & \\
\hline 2000 & 5.19 & 38.65 & 93.96 & 2445 & 42.94 & 4.37 & 36.28 & 435.87 & 497.94 \\
\hline 2001 & 5.11 & 38.14 & & 2552 & 42.94 & 4.23 & 36.91 & & \\
\hline 2002 & 5.04 & 37.70 & & 2215 & 42.93 & 4.12 & 37.54 & 592.50 & 631.50 \\
\hline 2003 & 5.02 & 37.47 & 92.36 & 2228 & 42.92 & 3.99 & 38.17 & & \\
\hline mean & 6.14 & 44.03 & 107.30 & 2,063 & 42.70 & 5.45 & 25.49 & 432.34 & 499.69 \\
\hline
\end{tabular}


Table 4: Summary Statistics for policy variables over years 1962-2003

\begin{tabular}{|c|c|c|c|c|c|c|c|c|c|c|c|c|}
\hline \multirow[b]{2}{*}{ year } & \multicolumn{2}{|c|}{$\begin{array}{c}\text { total } \\
\text { fertility }\end{array}$} & \multicolumn{2}{|c|}{$\begin{array}{l}\text { crude } \\
\text { fertility }\end{array}$} & \multicolumn{2}{|c|}{$\begin{array}{l}\text { prevalence of } \\
\text { HIV (15-49) } \\
\end{array}$} & \multicolumn{2}{|c|}{$\begin{array}{c}\text { health } \\
\text { expenditure }\end{array}$} & \multicolumn{2}{|c|}{$\begin{array}{c}\text { poverty headcount } \\
\text { ratio at } \$ 1 \text { a day }\end{array}$} & \multicolumn{2}{|c|}{$\begin{array}{c}\text { poverty headcount } \\
\text { ratio at \$2 a day }\end{array}$} \\
\hline & mean & obs & mean & obs & mean & obs & mean & obs & mean & obs & mean & obs \\
\hline 1962 & 6.54 & 43 & 47.76 & 43 & & & & & & & & \\
\hline 1963 & & & 40.40 & 1 & & & & & & & & \\
\hline 1964 & & & 38.90 & 1 & & & & & & & & \\
\hline 1965 & & & 36.00 & 1 & & & & & & & & \\
\hline 1966 & & & 36.00 & 1 & & & & & & & & \\
\hline 1967 & 6.55 & 43 & 47.18 & 43 & & & & & & & & \\
\hline 1968 & & & 31.60 & 1 & & & & & & & & \\
\hline 1969 & & & 27.70 & 1 & & & & & & & & \\
\hline 1970 & & & 27.50 & 1 & & & & & & & & \\
\hline 1971 & & & 26.10 & 1 & & & & & & & & \\
\hline 1972 & 6.56 & 43 & 46.82 & 43 & & & & & & & & \\
\hline 1973 & & & 23.00 & 1 & & & & & & & & \\
\hline 1974 & & & 33.80 & 3 & & & & & & & & \\
\hline 1975 & & & 32.93 & 3 & & & & & & & & \\
\hline 1976 & 4.50 & 1 & 32.93 & 3 & & & & & & & & \\
\hline 1977 & 6.59 & 44 & 45.85 & 45 & & & & & & & & \\
\hline 1978 & & & 32.60 & 3 & & & & & & & & \\
\hline 1979 & & & 31.13 & 3 & & & & & & & & \\
\hline 1980 & & & 28.05 & 2 & & & & & 49.18 & 1 & 80.26 & 1 \\
\hline 1981 & & & 26.80 & 2 & & & & & 32.73 & 1 & 82.92 & 1 \\
\hline 1982 & 6.47 & 46 & 44.83 & 46 & & & & & & & & \\
\hline 1983 & & & 23.40 & 2 & & & & & & & & \\
\hline 1984 & 2.16 & 1 & 23.50 & 2 & & & & & 35.73 & 1 & 84.55 & 1 \\
\hline 1985 & 2.02 & 1 & 22.75 & 2 & & & & & 49.51 & 2 & 76.11 & 2 \\
\hline 1986 & 1.99 & 1 & 22.45 & 2 & & & & & 16.81 & 2 & 40.65 & 2 \\
\hline 1987 & 6.24 & 47 & 43.95 & 46 & & & & & 33.55 & 3 & 64.49 & 3 \\
\hline 1988 & 2.14 & 1 & 20.10 & 1 & & & & & 45.45 & 1 & 84.46 & 1 \\
\hline 1989 & 4.57 & 2 & 20.80 & 1 & & & & & 53.72 & 3 & 75.65 & 3 \\
\hline 1990 & 5.99 & 46 & 43.01 & 46 & & & & & 33.32 & 1 & 75.37 & 1 \\
\hline 1991 & 2.30 & 1 & 20.70 & 1 & & & & & 44.18 & 4 & 73.60 & 4 \\
\hline 1992 & 5.84 & 46 & 42.35 & 47 & & & & & 53.21 & 6 & 83.30 & 6 \\
\hline 1993 & 3.66 & 2 & 20.30 & 1 & & & & & 39.39 & 10 & 66.81 & 10 \\
\hline 1994 & 5.55 & 6 & 28.55 & 2 & & & & & 42.37 & 4 & 65.43 & 4 \\
\hline 1995 & 5.02 & 8 & 19.65 & 2 & & & & & 31.84 & 8 & 64.44 & 8 \\
\hline 1996 & 3.08 & 2 & 19.70 & 2 & & & & & 59.85 & 5 & 85.43 & 5 \\
\hline 1997 & 5.41 & 47 & 40.04 & 47 & & & & & 40.90 & 3 & 73.74 & 3 \\
\hline 1998 & 3.77 & 2 & 23.90 & 3 & & & 5.03 & 47 & 44.68 & 5 & 76.99 & 5 \\
\hline 1999 & 3.48 & 3 & 17.75 & 2 & & & 4.94 & 47 & 67.00 & 2 & 89.96 & 2 \\
\hline 2000 & 2.04 & 2 & 17.80 & 2 & & & 4.96 & 47 & 27.82 & 4 & 64.66 & 4 \\
\hline 2001 & 1.95 & 2 & 17.05 & 2 & 9.05 & 38 & 5.07 & 47 & 39.07 & 2 & 67.87 & 2 \\
\hline 2002 & 5.04 & 47 & 37.70 & 47 & & & 5.23 & 46 & 10.80 & 1 & 38.40 & 1 \\
\hline 2003 & 5.02 & 47 & 37.47 & 47 & 8.81 & 38 & & & & & & \\
\hline mean & 4.40 & & 30.97 & & 8.93 & & 5.05 & & 40.53 & & 72.15 & \\
\hline
\end{tabular}


Table 5: Explaining the total fertility rate in Sub-Sahara African countries

\begin{tabular}{|l|c|c|c|c|c|c|}
\hline & \multicolumn{4}{|c|}{ original fertility data } & \multicolumn{2}{c|}{ interpolated fertility } \\
\hline & \multicolumn{2}{|c|}{1990} & \multicolumn{2}{c|}{$1962-2003$} & \multicolumn{2}{c|}{$1962-2003$} \\
\cline { 2 - 7 } & basic & extended & basic & extended & basic & extended \\
\hline Constant & 5.189 & 3.661 & 4.295 & 2.951 & 3.971 & 2.901 \\
& $(13.29)$ & $(4.69)$ & $(14.03)$ & $(4.39)$ & $(18.69)$ & $(6.25)$ \\
& {$[14.52]$} & {$[4.30]$} & {$[16.27]$} & {$[5.12]$} & {$[15.56]$} & {$[6.49]$} \\
\hline Infant & 0.01 & 0.01 & 0.02 & 0.02 & 0.02 & 0.02 \\
Mortality rate & $(4.40)$ & $(4.69)$ & $(7.00)$ & $(7.39)$ & $(11.61)$ & $(11.19)$ \\
& {$[4.34]$} & {$[4.46]$} & {$[7.83]$} & {$[8.77]$} & {$[10.16]$} & {$[11.71]$} \\
\hline GDP per capita & -0.0002 & -0.0002 & -0.0002 & -0.0001 & -0.0001 & -0.0001 \\
& $(-4.31)$ & $(-3.53)$ & $(-5.53)$ & $(-3.54)$ & $(-5.40)$ & $(-3.37)$ \\
& -4.68 & {$[-4.84]$} & {$[-6.76]$} & {$[-4.04]$} & {$[-3.75]$} & {$[-2.55]$} \\
\hline Urban population & & -0.004 & & -0.007 & & -0.010 \\
Percentage & & $(-0.53)$ & & $(-1.52)$ & & $(-2.93)$ \\
& & {$[-0.55]$} & & {$[-1.29]$} & & {$[-2.56]$} \\
\hline Urban population & & 0.119 & & 0.226 & & 0.211 \\
growth rate & & $(2.39)$ & & $(5.04)$ & & $(7.02)$ \\
& & {$[2.06]$} & & {$[5.31]$} & & {$[6.28]$} \\
\hline female labor & & 0.021 & & 0.011 & & 0.012 \\
participation & & $(1.46)$ & & $(0.86)$ & & $(1.38)$ \\
& & {$[1.67]$} & & {$[0.97]$} & & {$[1.48]$} \\
\hline No of observation & 41 & 40 & 91 & 89 & 204 & 198 \\
\hline $\mathrm{R}^{2}$ & 0.729 & 0.7951 & 0.7108 & 0.7917 & 0.6211 & 0.7291 \\
\hline adjusted R ${ }^{2}$ & 0.7151 & 0.7649 & 0.7042 & 0.7792 & 0.6173 & 0.722 \\
\hline
\end{tabular}

Note: Total fertility rate (births per woman), infant mortality rate (per 1,000 live births), GDP per capita (constant (2000) U.S. dollars), urban population (\% of total population), urban population growth (annual $\%$ ), and female labor force (\% of total labor force). The values in the parentheses are t-statistics and those in the brackets are Huber/White/Sandwich robust t-statistics. 
Table 6: Robust Check - Different definition of fertility: Crude birth rate

\begin{tabular}{|l|c|c|c|c|c|c|}
\hline & \multicolumn{3}{|c|}{ original fertility data } & \multicolumn{2}{c|}{ interpolated fertility } \\
\hline & \multicolumn{2}{|c|}{1990} & \multicolumn{2}{c|}{$1962-2003$} & \multicolumn{2}{c|}{$1962-2003$} \\
\cline { 2 - 8 } & basic & extended & basic & extended & basic & Extended \\
\hline constant & 32.421 & 22.796 & 29.869 & 19.579 & 29.452 & 22.433 \\
& $(16.03)$ & $(6.21$ & $(16.24)$ & $(-5.57)$ & $(25.51)$ & $(8.58)$ \\
& {$[18.2]$} & {$[6.05]$} & {$[18.18]$} & {$[6.86]$} & {$[22.51]$} & {$[9.01]$} \\
\hline infant & 0.12 & 0.12 & 0.13 & 0.13 & 0.13 & 0.12 \\
mortality rate & $(7.82)$ & $(9.19)$ & $(8.77)$ & $(10.08)$ & $(14.08)$ & $(14.06)$ \\
& {$[8.23]$} & {$[9.37]$} & {$[10.04]$} & {$[11.87]$} & {$[13.13]$} & {$[15.40]$} \\
\hline GDP per capita & -0.0007 & -0.0004 & -0.0010 & -0.0005 & -0.0006 & -0.0004 \\
& $(-2.43)$ & $(-1.62)$ & $(-4.53)$ & $(-2.64)$ & $(-4.67)$ & $(-2.97)$ \\
& {$[-2.55]$} & {$[-1.63]$} & {$[-4.20]$} & {$[-2.29]$} & {$[-3.35]$} & {$[-2.35]$} \\
\hline urban population & & -0.018 & & -0.010 & & -0.022 \\
percentage & & $(-0.52)$ & & $(-0.37)$ & & $(-1.10)$ \\
& & {$[-0.48]$} & & {$[-0.31]$} & & {$[-1.00]$} \\
\hline urban population & & 0.832 & & 1.508 & & 1.182 \\
growth rate & & $(3.55)$ & & $(5.98)$ & & $(6.97)$ \\
& & {$[3.09]$} & & {$[7.08]$} & & {$[6.01]$} \\
\hline female labor & & 0.118 & & 0.072 & & 0.056 \\
Participation & & $(1.70)$ & & $(1.06)$ & & $(1.15)$ \\
& & {$[2.17]$} & & {$[1.30]$} & & {$[1.30]$} \\
\hline no of observation & 42 & 41 & 86 & 84 & 203 & 198 \\
\hline $\mathrm{R}^{2}$ & 0.797 & 0.872 & 0.755 & 0.843 & 0.674 & 0.751 \\
\hline adjusted R ${ }^{2}$ & 0.786 & 0.853 & 0.750 & 0.832 & 0.671 & 0.745 \\
\hline
\end{tabular}

Note: The dependent variable is crude birth rate and the number of live births occurring during the year per 1,000 people estimated at midyear. See Table 5. 
Table 7: Explaining total fertility rate in the Panel Data Structure

\begin{tabular}{|c|c|c|c|c|}
\hline & \multicolumn{2}{|c|}{ Basic } & \multicolumn{2}{|c|}{ Extended } \\
\hline & FE & $\mathrm{RE}$ & FE & RE \\
\hline Constant & & $\begin{array}{c}3.585 \\
(13.94) \\
{[10.00]}\end{array}$ & & $\begin{array}{l}3.743 \\
(5.26) \\
{[4.48]}\end{array}$ \\
\hline $\begin{array}{l}\text { Infant } \\
\text { mortality rate }\end{array}$ & $\begin{array}{l}0.029 \\
(8.21) \\
{[6.01]}\end{array}$ & $\begin{array}{c}0.023 \\
(10.79) \\
{[7.68]}\end{array}$ & $\begin{array}{l}0.010 \\
(2.99) \\
{[1.92]}\end{array}$ & $\begin{array}{l}0.017 \\
(8.28) \\
{[8.34]}\end{array}$ \\
\hline GDP per capita & $\begin{array}{c}0.000 \\
(-1.03) \\
{[-0.58]} \\
\end{array}$ & $\begin{array}{c}0.000 \\
(-3.14) \\
{[-2.00]}\end{array}$ & $\begin{array}{l}0.000 \\
(0.91) \\
{[1.11]}\end{array}$ & $\begin{array}{c}0.000 \\
(-1.04) \\
{[-0.87]} \\
\end{array}$ \\
\hline $\begin{array}{l}\text { urban populaton } \\
\text { Percentage }\end{array}$ & & & $\begin{array}{l}-0.049 \\
(-5.69) \\
{[-2.62]}\end{array}$ & $\begin{array}{l}-0.023 \\
(-4.41) \\
{[-2.45]} \\
\end{array}$ \\
\hline $\begin{array}{l}\text { urban population } \\
\text { Growth rate }\end{array}$ & & & $\begin{array}{l}0.154 \\
(4.35) \\
{[3.08]}\end{array}$ & $\begin{array}{l}0.198 \\
(6.72) \\
{[5.04]}\end{array}$ \\
\hline $\begin{array}{l}\text { Female labor } \\
\text { Participation }\end{array}$ & & & $\begin{array}{c}-0.119 \\
(-2.8) \\
{[-2.45]}\end{array}$ & $\begin{array}{c}-0.0001 \\
(-0.00) \\
{[-0.00]}\end{array}$ \\
\hline no of obs & 204 & 204 & 198 & 198 \\
\hline $\mathrm{R}^{2}$-within & 0.304 & 0.293 & 0.608 & 0.557 \\
\hline $\mathrm{R}^{2}$-between & 0.703 & 0.741 & 0.206 & 0.764 \\
\hline $\mathrm{R}^{2}$-oversall & 0.591 & 0.615 & 0.277 & 0.708 \\
\hline Hausman test & & 25 & & 00 \\
\hline p-value & & 10 & & 549 \\
\hline Decision & & $\mathrm{E}$ & & $\mathrm{E}$ \\
\hline
\end{tabular}

Note: Due to the data restriction in the panel structure, the interpolated total fertility rate is used in the analysis (See Table 5). The values in the parentheses are t-statistics and those in the brackets are Huber/White/Sandwich robust t-statistics with adjustment of standard errors within country correlation. 
Table 8: Policy modeling with the pooling Data Structure

\begin{tabular}{|l|c|c|c|c|c|c|c|c|}
\hline & benchmark & Model 1 & Model 2 & Model 3 & Model 4 & Model 5 & Model 6 \\
\hline Constant & 3.971 & 4.406 & 3.762 & 3.651 & 3.937 & 3.777 & 3.057 \\
& $(18.69)$ & $(9.69)$ & $(12.02)$ & $(10.25)$ & $(10.26)$ & $(9.06)$ & $(4.95)$ \\
& {$[15.56]$} & {$[9.91]$} & {$[13.4]$} & {$[9.90]$} & {$[10.09]$} & {$[10.11]$} & {$[5.69]$} \\
\hline Infant & 0.02 & 0.020 & 0.020 & 0.021 & 0.020 & 0.016 & 0.016 \\
mortality rate & $(11.61)$ & $(7.65)$ & $(7.03)$ & $(8.60)$ & $(6.97)$ & $(5.41)$ & $(5.3)$ \\
& {$[10.16]$} & {$[6.41]$} & {$[7.48]$} & {$[6.34]$} & {$[7.52]$} & {$[5.62]$} & {$[6.15]$} \\
\hline GDP per capita & -0.0001 & -0.0001 & -0.0001 & -0.0001 & -0.0001 & -0.0001 & -0.0001 \\
& $(-5.40)$ & $(-3.80)$ & $(-2.47)$ & $(-3.94)$ & $(-2.35)$ & $(-2.82)$ & $(-1.89)$ \\
& {$[-3.75]$} & {$[-2.45]$} & {$[-2.77]$} & {$[-2.24]$} & {$[-2.87]$} & {$[-3.17]$} & {$[-2.16]$} \\
\hline mortality rate & & -0.004 & & & & & \\
Female & & $(-1.44)$ & & & & & \\
& & {$[-1.42]$} & & & & & \\
\hline mortality rate & & 0.003 & & & & & \\
Male & & $(0.95)$ & & & & & \\
& & {$[0.97]$} & & & & & \\
\hline prevalence of HIV & & & -0.023 & & -0.021 & & \\
(15-49) & & & $(-2.71)$ & & $(-2.47)$ & & \\
& & & & -0.043 & -0.036 & & \\
\hline health expenditure & & & & $(-1.00)$ & $(-0.79)$ & & \\
& & & & {$[-0.84]$} & {$[-0.69]$} & & \\
\hline poverty headcount & & & & & & 0.013 & \\
ratio at \$1 a day & & & & & & $(3.27)$ & \\
\hline poverty headcount & & & & & & & 0.017 \\
ratio at \$2 a day & & & & & & & $(2.85)$ \\
& & & & & & & {$[2.67]$} \\
\hline no of observation & 204 & 113 & 73 & 84 & 73 & 49 & 49 \\
\hline $\mathrm{R}^{2}$ & 0.621 & 0.5882 & 0.6718 & 0.6746 & 0.6748 & 0.741 & 0.7285 \\
\hline adjusted $\mathrm{R}^{2}$ & 0.617 & 0.5729 & 0.6576 & 0.6624 & 0.6557 & 0.7237 & 0.7104 \\
\hline
\end{tabular}

Note: The dependent variable is the interpolated total fertility rate (births per woman). Of the independent variables, data for GDP per capita are in constant 2,000 U.S. dollars, poverty headcount ratio at \$1 (\$2) per day is the percentage of the population living on less than $\$ 1.08$ (\$2.15) a day at 1993 international prices. 
Appendix Table 1: Summary Statistics for demographic variables across countries

\begin{tabular}{|c|c|c|c|c|c|c|c|c|c|c|c|}
\hline & country name & region & $\begin{array}{c}\text { total } \\
\text { fertility } \\
\text { (interpolated) } \\
\end{array}$ & \begin{tabular}{|c|} 
crude \\
fertility \\
(interpolated) \\
\end{tabular} & $\begin{array}{c}\text { infant } \\
\text { mortality } \\
\text { rate }\end{array}$ & \begin{tabular}{|c|} 
GDP \\
per \\
capita
\end{tabular} & $\begin{array}{c}\text { urban } \\
\text { population } \\
\text { percentage }\end{array}$ & \begin{tabular}{|c|} 
urban \\
population \\
growth rate
\end{tabular} & \begin{tabular}{|c|} 
female \\
labor \\
participation
\end{tabular} & $\begin{array}{c}\text { mortality } \\
\text { rate } \\
\text { female }\end{array}$ & $\begin{array}{c}\text { mortality } \\
\text { rate } \\
\text { male }\end{array}$ \\
\hline 1 & Angola & Southern & 6.86 & 50.14 & 159.00 & 2135 & 46.87 & 5.43 & 22.94 & 424.63 & 509.98 \\
\hline 2 & Benin & West & 6.59 & 46.43 & 112.50 & 877 & 47.99 & 6.36 & 28.03 & 358.63 & 432.34 \\
\hline 3 & Botswana & Southern & 5.67 & 42.50 & 68.67 & 4969 & 49.57 & 11.14 & 26.31 & 473.60 & 529.06 \\
\hline 4 & Burkina Faso & West & 7.04 & 46.81 & 124.17 & 905 & 49.56 & 5.50 & 10.35 & 403.44 & 495.33 \\
\hline 5 & Burundi & Central & 6.64 & 44.39 & 118.33 & 757 & 49.84 & 5.86 & 5.10 & 475.32 & 547.17 \\
\hline 6 & Cameroon & West & 5.91 & 42.44 & 99.83 & 2077 & 37.33 & 5.79 & 33.10 & 417.04 & 487.77 \\
\hline 7 & Cape Verde & West & 5.84 & 37.86 & 39.80 & 3880 & 34.94 & 5.48 & 34.91 & 216.81 & 270.64 \\
\hline 8 & Central African Republic & Central & 5.47 & 41.05 & 121.67 & 1285 & 48.01 & 3.66 & 34.86 & 454.44 & 554.07 \\
\hline 9 & Chad & West & 6.55 & 45.16 & 119.60 & 904 & 43.58 & 5.51 & 17.70 & 424.68 & 511.47 \\
\hline 10 & Comoros & Southern & 5.79 & 38.63 & 92.67 & 1833 & 43.48 & 4.42 & 24.57 & 316.04 & 372.85 \\
\hline 11 & Congo, Dem. Rep. & Central & 6.51 & 47.36 & 132.83 & 1446 & 44.42 & & & 493.00 & 571.00 \\
\hline 12 & Congo, Rep. & Central & 6.26 & 44.95 & 85.67 & 902 & 42.37 & 4.98 & 46.90 & 342.80 & 441.86 \\
\hline 13 & Cote d'Ivoire & West & 6.60 & 46.17 & 119.50 & 1876 & 32.36 & 5.55 & 34.88 & 390.49 & 462.95 \\
\hline 14 & Equatorial Guinea & West & 5.74 & 42.35 & 123.83 & 4089 & 35.70 & 3.35 & 33.27 & 395.53 & 487.23 \\
\hline 15 & Eritrea & East & 6.21 & 39.09 & 73.60 & 816 & 47.49 & 4.64 & 14.39 & 394.11 & 463.24 \\
\hline 16 & Ethiopia & East & 6.23 & 48.38 & 130.83 & 633 & 42.06 & 4.88 & 11.28 & 426.24 & 503.98 \\
\hline 17 & Gabon & West & 4.46 & 33.88 & 62.60 & 6697 & 44.91 & 6.14 & 53.47 & 367.68 & 443.95 \\
\hline 18 & Gambia, The & West & 6.08 & 46.26 & 118.00 & 1694 & 44.85 & 5.66 & 21.43 & 434.28 & 535.40 \\
\hline 19 & Ghana & West & 5.94 & 41.25 & 79.17 & 1748 & 50.51 & 3.68 & 31.57 & 326.60 & 393.20 \\
\hline 20 & Guinea & West & 5.82 & 44.87 & 143.67 & 1831 & 47.43 & 4.73 & 19.86 & 475.36 & 546.43 \\
\hline 21 & Guinea-Bissau & West & 6.90 & 48.97 & 145.40 & 844 & 40.14 & 4.60 & 20.93 & 497.56 & 525.72 \\
\hline 22 & Kenya & East & 6.78 & 45.28 & 76.83 & 1037 & 45.98 & 7.09 & 19.38 & 383.76 & 454.78 \\
\hline 23 & Lesotho & Southern & 5.29 & 38.98 & 87.00 & 1411 & 37.65 & 6.80 & 16.04 & 395.34 & 467.92 \\
\hline 24 & Liberia & West & 6.64 & 47.30 & 160.83 & & 38.78 & 4.97 & 35.11 & 270.33 & 352.01 \\
\hline 25 & Madagascar & Southern & 6.27 & 45.35 & 95.83 & 932 & 44.89 & 5.31 & 20.30 & 306.72 & 380.76 \\
\hline 26 & Malawi & Southern & 7.07 & 52.37 & 142.33 & 555 & 49.96 & 5.83 & 9.71 & 456.48 & 521.96 \\
\hline 27 & Mali & West & 6.93 & 49.83 & 153.00 & 758 & 46.38 & 4.90 & 20.54 & 393.75 & 485.86 \\
\hline 28 & Mauritania & West & 6.00 & 42.86 & 106.50 & 1592 & 45.19 & 8.16 & 32.57 & 378.77 & 460.24 \\
\hline 29 & Mauritius & Southern & 2.90 & 24.11 & 28.50 & 7047 & 26.47 & 1.95 & 40.91 & 157.30 & 245.80 \\
\hline 30 & Mozambique & Southern & 6.17 & 44.64 & 132.33 & 699 & 48.90 & 7.69 & 16.31 & 418.82 & 514.70 \\
\hline 31 & Namibia & Southern & 5.64 & 39.95 & 61.50 & 6266 & 40.92 & 4.62 & 23.71 & 437.60 & 494.10 \\
\hline 32 & Niger & West & 7.77 & 54.99 & 178.00 & 939 & 44.03 & 6.36 & 13.52 & 416.07 & 540.10 \\
\hline 33 & Nigeria & West & 6.59 & 47.29 & 113.83 & 867 & 35.92 & 5.68 & 29.68 & 437.00 & 514.84 \\
\hline 34 & Rwanda & Central & 7.45 & 48.21 & 119.50 & 1162 & 49.28 & 5.28 & 4.60 & 454.72 & 541.22 \\
\hline 35 & Sao Tome and Principe & West & 4.77 & 37.70 & 75.00 & & & 4.95 & 32.96 & 226.00 & 269.00 \\
\hline 36 & Senegal & West & 6.40 & 45.09 & 104.00 & 1422 & 42.21 & 3.83 & 38.26 & 426.88 & 500.32 \\
\hline 37 & Seychelles & East & 2.93 & 23.92 & 14.25 & & & 3.95 & 43.81 & 184.83 & 278.70 \\
\hline 38 & Sierra Leone & West & 6.33 & 47.98 & 179.50 & 841 & 35.88 & 5.03 & 25.48 & 521.00 & 570.00 \\
\hline 39 & Somalia & East & 7.22 & 51.48 & 133.00 & & 43.59 & 4.22 & 23.01 & 446.89 & 536.12 \\
\hline 40 & South Africa & Southern & 4.35 & 34.15 & 51.40 & 10137 & 35.37 & 2.83 & 49.93 & 462.09 & 536.38 \\
\hline 41 & Sudan & East & 5.83 & 41.48 & 76.83 & 1317 & 27.44 & 5.71 & 23.22 & 418.94 & 489.33 \\
\hline 42 & Swaziland & Southern & 5.74 & 43.02 & 98.33 & 3784 & 34.18 & 7.49 & 18.02 & 394.08 & 458.51 \\
\hline 43 & Tanzania & East & 6.35 & 45.76 & 108.00 & 514 & 49.98 & 8.00 & 17.12 & 420.63 & 494.15 \\
\hline 44 & Togo & West & 6.31 & 43.65 & 93.83 & 1707 & 39.47 & 5.88 & 22.87 & 383.23 & 458.60 \\
\hline 45 & Uganda & East & 6.93 & 48.95 & 93.00 & 1010 & 47.59 & 5.81 & 9.95 & 454.09 & 513.25 \\
\hline 46 & Zambia & Southern & 6.43 & 46.82 & 101.00 & 999 & 44.04 & 4.80 & 35.40 & 484.16 & 546.87 \\
\hline \multirow[t]{2}{*}{47} & Zimbabwe & Southern & 5.79 & 41.38 & 69.83 & 2600 & 44.22 & 5.60 & 24.31 & 398.50 & 453.25 \\
\hline & mean & & 6.08 & 43.65 & 104.79 & 2088 & 42.71 & 5.44 & 25.49 & 396.52 & 471.58 \\
\hline
\end{tabular}


Appendix Table 2: Summary Statistics for policy variables across countries

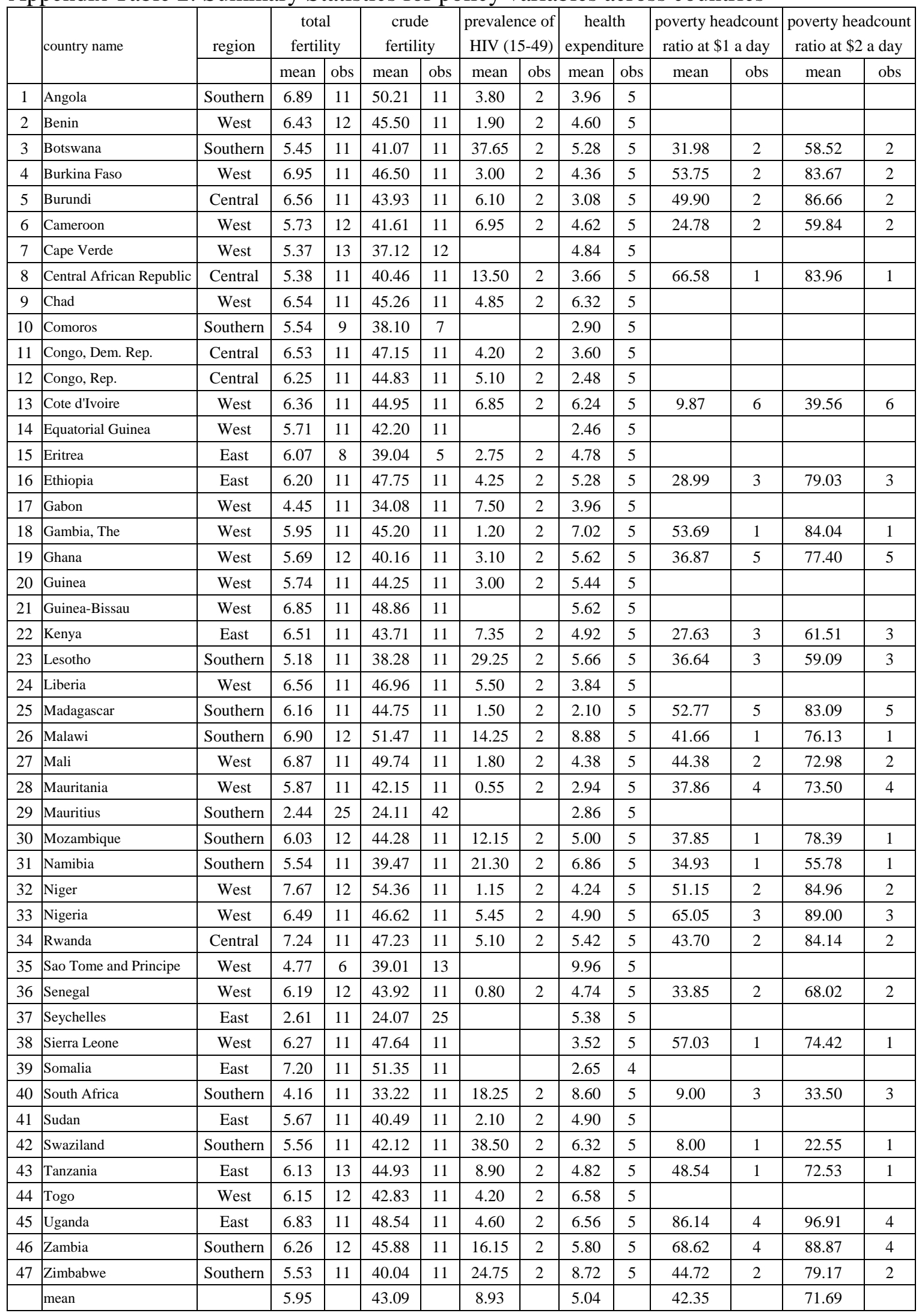




\section{Appendix: Variable Lists}

\section{Dependent variable}

Total fertility rate (births per woman) - Total fertility rate represents the number of children that would be born to a woman if she were to live to the end of her childbearing years and bear children in accordance with prevailing age-specific fertility rates.

Crude birth rate (per 1,000 people) - Crude birth rate indicates the number of live births occurring during the year, per 1,000 population estimated at midyear.

\section{Independent variables}

Female adult mortality rate (per 1,000 female adults) - Adult mortality rate is the probability of dying between the ages of 15 and 60--that is, the probability of a 15-yearold dying before reaching age 60, if subject to current age-specific mortality rates between ages 15 and 60 .

Male adult mortality rate (per 1,000 male adults) - Adult mortality rate is the probability of dying between the ages of 15 and 60--that is, the probability of a 15-yearold dying before reaching age 60, if subject to current age-specific mortality rates between ages 15 and 60 .

Infant mortality rate (per $\mathbf{1 , 0 0 0}$ live births) - Infant mortality rate is the number of infants dying before reaching one year of age, per 1,000 live births in a given year.

GDP per capita (constant 2,000 US\$) - GDP per capita is gross domestic product divided by midyear population. GDP is the sum of gross value added by all resident producers in the economy plus any product taxes and minus any subsidies not included in the value of the products. Data are in constant U.S. dollars.

Female Labor force (\% of total labor force) - Female labor force as a percentage of the total show the extent to which women are active in the labor force. Labor force comprises all people who meet the International Labour Organization's definition of the economically active population.

Urban population (\% of total) - Urban population is the share of the total midyear population living in areas defined as urban in each country.

Urban population growth (annual \%) - Urban population is the midyear population of areas defined as urban in each country that is reported to the United Nations.

Poverty headcount ratio at $\$ 1$ a day (PPP) (\% of population) - Population below \$1 a day is the percentage of the population living on less than $\$ 1.08$ a day at 1993 international prices. As a result of revisions in PPP exchange rates, poverty rates cannot 
be compared with poverty rates reported previously for individual countries. Data showing as 2.0 signifies a poverty rate of less than 2.0 percent.

Poverty headcount ratio at $\mathbf{\$ 2}$ a day (PPP) (\% of population) - Population below $\$ 2$ a day is the percentage of the population living on less than $\$ 2.15$ a day at 1993 international prices. As a result of revisions in PPP exchange rates, poverty rates cannot be compared with poverty rates reported previously for individual countries. Data showing as 2.0 signifies a poverty rate of less than 2.0 percent.

Total prevalence of HIV (\% of population aged 15-49) - Prevalence of HIV (Human Immunodeficiency Virus) refers to the percentage of people ages 15-49 who are infected with HIV.

Total health expenditure (\% of GDP) - Total health expenditure is the sum of public and private health expenditure. It covers the provision of health services (preventive and curative), family planning activities, nutrition activities, and emergency aid designated for health but does not include provision of water and sanitation. 